\title{
Critical Thinking Strategies in Reading
}

\author{
Feryal CubukCu \\ Dokuz Eylul University \\ Turkey
}

Received: 20 June 2010 / Accepted: 12 September 2010

ISSN: $1697-7467$

\begin{abstract}
The social negotiation maintains that the main roles of the environment are to offer alternative views, to develop knowledge, to seek knowledge that is compatible with students' own construction and understanding of the world. It also enhances critical thinking skills such as studying a subject or problem with openmindedness, determining the facts of a new situation or subject without prejudice, placing these facts and information in a pattern so that students can understand them and accepting or rejecting the source values and conclusions based upon experience, judgment, and beliefs. When students assimilate their current experience with their existing schema, it becomes easier for them to retain learning (Fink, 2003). In this paper, the aim is to show how critical thinking strategies can be used for young learners in reading classes by demonstrating the main steps in the hierarchy of Bloom's taxonomy and applying them to the fairy tales, which lead the learners to show some improvement in their critical thinking strategies.
\end{abstract}

Keywords: Reading, critical thinking, schema, analysis, synthesis.

\section{Estrategias de pensamiento crítico en la lectura}

RESUMEN: La negociación social sostiene que las principales funciones del medio ambiente son ofrecer puntos de vista alternativos, para desarrollar el conocimiento, buscar el conocimiento que es compatible con la construcción de los propios estudiantes y la comprensión del mundo. También mejora la capacidad de pensamiento crítico como el estudio de un tema o problema con apertura de espíritu, la determinación de los hechos de una nueva situación o tema sin prejuicios, para todos estos hechos y la información en un modelo de fprma que los estudiantes puedan comprender y aceptar o rechazar los valores y conclusiones basadas en la experiencia, el juicio y las creencias. Cuando los estudiantes asimilan su experiencia cotidiana con sus esquemas mentales existentes, se hace más fácil para ellos conseguir el aprendizaje (Fink, 2003). En este articulo, el objetivo es mostrar lo importante que las estrategias de pensamiento pueden ser para los jóvenes estudiantes en clases de lectura mediante la demostración de los pasos principales en la jerarquía de la taxonomía de Bloom y su aplicación a los cuentos de hadas, que conducen a los alumnos hacia una mejora de sus estrategias de pensamiento crítico.

Palabras clave: la lectura, el pensamiento crítico, el esquema, el análisis, la síntesis. 


\section{INTRODUCTION}

Various definitions of critical thinking exist, with most focusing on the ability to develop and analyze arguments based on available resources and knowledge (Angelo, 1995; Williams, Oliver, \& Stockdale, 2004;Williams \& Worth, 2001). For example, Browne and Stuart (2004:3) argue that "critical thinking consists of an awareness of a set of interrelated critical questions, plus the ability and willingness to ask and answer them at appropriate times». Facione (1998) contends that the skills of interpretation, analysis, evaluation, inference, explanation, and self-regulation are at the core of critical thinking. Other scholars (O'Keefe, 1986) claim that critical thinking cannot be limited to concepts such as logic and evaluation. Critical thinking is more than just a variety of concepts; it is a set of abilities. Ennis (2003:295) defines critical thinking as «reasonable reflective thinking focused on deciding what to believe or do».

From the cognitive scientists' point of view, the mental activities that are typically called critical thinking are actually a subset of three types of thinking: reasoning, making judgments/ decisions, and problem solving. Critical thinking is a subset of these because we think in these ways all the time, but only sometimes in a critical way. Deciding to read this article, for example, is not critical thinking. But carefully weighing the evidence it presents in order to decide whether or not to believe what it says is. Critical reasoning, decision making, and problem solving have three key features: effectiveness, novelty, and self-direction. Critical thinking is effective in that it avoids common pitfalls, such as seeing only one side of an issue, discounting new evidence that disconfirms your ideas, reasoning from passion rather than logic, failing to support statements with evidence, and so on. Critical thinking is novel in that you do not simply remember a solution or a situation that is similar enough to guide you. For example, solving a complex and familiar physics problem by applying a multi-step algorithm is not critical thinking because you are really drawing on memory to solve the problem. But devising a new algorithm is critical thinking. Critical thinking is self-directed in that the thinker must be calling the shots: We would not give a student much credit for critical thinking if the teacher were prompting each step he took. (Willingham, 2008: 27)

The ideal critical thinker is habitually inquisitive, well informed, trustful of reason, open minded, flexible, fair minded in evaluation, honest in facing personal biases, prudent in making judgments, willing to reconsider, clear about issues, orderly in complex matters, diligent in seeking relevant information, reasonable in the selection of criteria, focused in inquiry, and persistent in seeking results which are as precise as the subject and the circumstances of inquiry permit (Facione, 1990: 2). Brookfield (1987) believed that we would know a critical thinker when we saw one. He characterized critical thinkers as people: engaging in productive and positive activity, viewing their thinking as a process rather than an outcome, varying in their manifestations of critical thinking according to context, experiencing triggers of critical thinking as positive or negative, and feeling comfortable with the emotive as well as the rational elements of the critical thinking process.

One immutable interpretation of the concept of critical thinking throughout the literature and congruent with the foundational tenets of critical social theory, is its 
emancipatory potential (Ray, 1992; Ford \& Profetto McGrath, 1994; Porter, 1994; Henderson, 1995; Conger \& Mezza, 1996). To Apps (1985: 151), emancipatory learning is that which frees people from personal, institutional, or environmental forces that prevent them from seeing new directions, from gaining control of their lives, their society and their world.

A second concept integral to critical thinking is the dialectical thinking (Paul, 1990), which involves our recognition of the assumptions underlying our beliefs and behaviours, which returns us to the key component of critical thinking reaction, and which focuses on understanding and resolving contradictions (Brookfield, 1987) and the components of critical thinking consist of four key issues; these elements appear insistently in the literature. Identifying and challenging assumptions is central to critical thinking. Once assumptions are exposed, they can be examined for accuracy and validity. Second, the importance of context to critical thinking is crucial. Recognizing that action in practice is never context free, critical thinkers have a heightened awareness of how assimilated assumptions shape their perceptions, understandings and interpretations of the world. Exploring and imagining alternatives is the third component. Critical thinkers are continually trying to uncover new and different ways of perceiving their world. Finally, imagining and exploring leads the critical thinker to reactive scepticism. Scepticism born of communicative action and reaction cautions one in the acceptance of universal truths.

Virtually everyone would agree that a primary, yet insufficiently met, goal of schooling is to enable students to think critically. In layperson's terms, critical thinking means being able to see both sides of an issue, being open to new evidence that disconfirms your ideas, reasoning dispassionately, demanding that claims be backed by evidence, deducing and inferring conclusions from available facts, solving problems, and so forth. Then too, there are specific types of critical thinking that are characteristic of different subject matter (Willingham, 2008: 21).

\section{THEORETICAL FRAMEWORK}

In the US there have been attempts to teach critical thinking strategies after 1980s. In 1983, A Nation At Risk, a report by the National Commission on Excellence in Education, found that many 17-year-olds did not possess the "'higher order' intellectual skills» this country needed. It claimed that nearly 40 percent could not draw inferences from written material and only one-fifth could write a persuasive essay. Following the release of A Nation At Risk, programs designed to teach students to think critically across the curriculum became extremely popular. By 1990, most states had initiatives designed to encourage educators to teach critical thinking. But, the educators in the USA still lament students' lack of critical thinking. Colleges and universities across the country are recognizing the need to integrate critical thinking instruction into general education programs (Halpern, 2001). Although most first-year students may have had some previous critical thinking instruction prior to entering a university's general education program, the critical thinking skills of these students are still in need of further development (Jacobson \& Mark, 2000). Scholars agree that critical thinking skills are necessary for everyone, not only in the classroom but also as a lifelong skill (Browne \& Stuart, 2004; O'Keefe, 1986, 1995). The introductory communication course provides an ideal context 
for the application of critical thinking (Hunt, Novak, Semlak, \& Meyer, 2005) because speech and thought are inextricably linked (Dance, 2002; O'Keefe, 1986, 1995).

Educators have long noted that school attendance and even academic success are no guarantee that a student will be an effective thinker in all situations. There is an odd tendency for rigorous thinking to cling to particular examples or types of problems. Thinking tends to focus on the problem's surface structure but with deep knowledge, thinking can penetrate beyond surface structure. When one is very familiar with a problem's deep-structure, knowledge about how to solve it transfers well. That familiarity can come from long-term, repeated experience with one problem, or with various manifestations of one type of problem (many problems that have different surface structures, but the same deep structure). After repeated exposure to either or both, the subject simply perceives the deep structure as part of the problem description. Since critical thinking relies so heavily on domain knowledge, educators may wonder if thinking critically in a particular domain is easier to learn. The quick answer is that it is a little easier (Willingham, 2008: 24)

Many scholars agree that critical thinking skills are necessary for academic success. For instance, Williams and Stockdale (2003) argue that high-critical thinking students are more likely to succeed academically than low-critical thinking students. Low critical thinking students are the least likely to improve their critical thinking skills and have a decreased chance of succeeding in courses that require critical thinking (Bowles, 2000; Gadzella, Ginther, \& Bryant, 1997). Those who develop critical thinking pedagogy must be mindful of the fact that classrooms consist of both high and low critical thinkers. Additionally, instructors should make attempts to use a variety of instructional approaches that appeal to different cognitive and learning styles (Hunt, Meyer, \& Lippert, 2006). In addition to promoting academic success, critical thinking skills are also essential if students are to become critical consumers and producers of information in a democratic society (Browne \& Stuart, 2004; O'Keefe, 1995). Studies have found that critical thinking skills taught in academia are applicable to everyday life (Lehman, Lempert, \& Nisbett, 1988; Lehman \& Nisbett, 1990). Tsui (2000: 435) claims that «graduates who can think critically become more productive and successful alumni and citizens». Instructors can foster this type of critical thinking by requiring students to apply critical thinking skills to collegiate experiences outside of the classroom (Mazer, Hunt \& Kuznekoff, 2007: 178)

Much of the current scholarship on reading and writing about various texts addresses literary and rhetorical interpretations suitable for specific age groups (Newell \& Durst, 1993; Marshall, Smagorinsky \& Smith, 1994). However, there are few in-depth studies of the similarities among interpretative strategies used by upper-elementary, secondary and high school students, and little attention has been given to the implications of either early training in critical reading and writing or later development of critical thinking strategies. In this paper, the aim is to bridge the gap that so often deters primary, secondary and high school teachers from discussing their students' reading and writing strategies with their colleagues at the university. Many teachers assume that students approach texts from similar vantage points. They expect specific answers to questions they ask about reading; they create writing assignments with a good response in mind; and they give quizzes that underline the importance of specific and often teacherprompted readings of a text. Although they know that students bring different experiences to the classroom, they often forget that those experiences influence how students 
approach and write about a text. However, John Dewey (1938: 49) already pointed out that 'attentive care must be devoted to the conditions which give a present experience a worthwhile meaning'. To achieve such meaning, Dewey considered it important that control is derived through the community and that all individuals participate in the activities and contribute to the process of meaning making (56). Education, in this setting, is a 'social process' (58) that is multidirectional and shared by a group of learners. In addition, Dewey argued that the activities used to reach an intended purpose depend on the maturity of the learners, thus proposing that thinking and reasoning skills develop with experiences (Gruber and Boreen, 2003: 7). The following study is conducted to answer the reasearch question : Do students in primary school demonstrate a higher level of group critical thinking after the critical strategy training as compared to a control group?

\section{Methodology}

\subsection{Participants}

Two classes at the state primary school in Buca were chosen haphazardly and 80 fifth graders (42 boys and 38 girls) participated in the study. They were given the the rubric on critical thinking skills before and after the intervention which lasted for 3 weeks. In the intervention group students studied three fairy tales (The Red Riding Hood, The Sleeping Beauty, and the Snow White) through critical thinking strategies. In the control group students discussed the texts through comprehension questions. All participation was voluntary and confidentiality of testing outcome was assured and maintained.

\subsection{Procedure}

Bloom's taxonomy is used here for the intervention group. The best way to approach and apply critical thinking strategies and to categorize dimensions is to use Bloom's taxonomy: from simple to more complex (1-6) operations are as follows for the simplicity, and the researcher used the Red Riding Hood as the first tale and the example of the application of the taxonomy.

\begin{tabular}{|l|l|l|}
\hline 1. & List, label, identify & Demonstrate knowledge \\
\hline 2. & $\begin{array}{l}\text { Define, explain, summarize in your } \\
\text { own words }\end{array}$ & Comprehend/understand \\
\hline 3. & Solve, apply to a new situation & Use your learning; apply it \\
\hline 4. & $\begin{array}{l}\text { Compare and contrast, differentiate } \\
\text { between items }\end{array}$ & Analyze \\
\hline 5. & Create, combine, invent & Synthesize \\
\hline 6. & Assess, recommend, value & Evaluate and explain why \\
\hline
\end{tabular}


Level 1 Recall is about remembering previously learned material, recalling facts, terms, basic concepts from the stated text.

Name Red Riding Hood

List the character names

Tell the story of each character

Recognize Mother,grandma, Red Riding Hood

Recall what the mother says.

Level 2 Comprehension

Understand means demonstrating understanding of the stated meaning of facts and ideas.

Explain why she goes to her grandma

Describe what she takes to her grandma

Rephrase the story

Show the different settings in the story

Organize the character definitions

Level 3 Application

Solving problems by applying acquired knowledge ,facts, and techniques in a different situation

Dramatize: Demonstrate how Red Riding Hood acted when she saw the wold in grandma's cottage.

Construct: the plot

Restructure: the little girl's position

Translate: change the gender of the story.

Practice the meeting scene

Experiment: How would you feel if you were in the shoes of the Red Riding Hood.

Level 4 Analysis

Examining and breaking down information into parts.

Analyse the character development

Simplify the story

Diagram: use diagrams to present the relationships of the characters

Summarize the plot

Classify the male and female characters

Categorize the major and minor characters

Level 5 Synthesis

Compiling information in a different way by combining elements in a new pattern.

Compose the given message

Elaborate the relation between the two different cultures

Design the plot where the red riding hood becomes victorious

Formulate how women are shown and how men are depicted.

Develop: restructure the events in a different way;

Originate: rewrite the story so that it will suit your cultural /personal taste

Solve the problems that seem to be causing trouble 
Level 6 Evaluation

Presenting and defending opinions by making judgments about information based on criteria

Judge the wolf's attitude

Defend the wolf/the hunter

Rank in which order the characters should be introduced

Justify any of the characters' position

Rate the positive attitudes of the characters

Evaluate the ending of the story

Recommend the story to other people negatively

Prove that this is a typical patriarchal society's depiction of women and the way they suppress women.

\subsection{Instruments}

Both groups were evaluated by the Holistic Critical Thinking Scoring Rubric (Facione $\&$ Facione, 1996), which was used to measure critical thinking. The template was a paper copy of the web-based form students would be completing online in future case study homework assignments. Its interrater reliability was measured as .86 . The template included the following steps:

1. Identify the problem.

2. Determine the underlying causes and symptoms of the problem.

3. Identify any unstated assumptions you are making and determine whether they are justifiable.

4. Brainstorm and list several strategies for resolution of case.

5. Evaluate each alternative, and then choose and rank your top 3 strategies according to its effectiveness.

6. List your top 3 recommendations and present a rationale for each.

The rubric taken from Facione (1996) is presented below.

Strong 4. Consistently does all or almost all of the following: Accurately interprets evidence, thoughtfully analyzes and evaluates major alternative points of view, draws warranted, judicious, non-fallacious conclusions.

Acceptable 3. Does most or many of the following: Accurately interprets evidence, offers analyses and evaluations of obvious alternative points of view, draws warranted, non-fallacious conclusions.

Unacceptable 2. Does most or many of the following: misinterprets evidence, statements, graphics, questions, etc, fails to identify strong, relevant counter-arguments. Ignores or superficially evaluates obvious alternative points of view.

Weak 1. Consistently does all or almost all of the following: Offers biased interpretations of evidence, statements, graphics, ignores or superficially evaluates obvious alternative points of view, argues using fallacious or irrelevant reasons, and unwarranted claims. 


\section{RESUlts}

Table 1 Significant Independent Variables for Students $(N=80)$.

\begin{tabular}{|c|c|c|c|}
\hline & & Mean & Standard Deviation \\
\hline $\begin{array}{l}\text { Inference- } \\
\text { comparing and } \\
\text { justifying }\end{array}$ & $\begin{array}{l}\text { Control } \\
\text { Intervention }\end{array}$ & $\begin{array}{l}2.335 \\
3.280\end{array}$ & $\begin{array}{l}1.475 \\
1.802\end{array}$ \\
\hline $\begin{array}{l}\text { Resolutions- } \\
\text { problem solutions }\end{array}$ & $\begin{array}{l}\text { Control } \\
\text { Intervention }\end{array}$ & $\begin{array}{l}2.464 \\
3.385\end{array}$ & $\begin{array}{l}2.273 \\
2.226\end{array}$ \\
\hline $\begin{array}{l}\text { Deduction- } \\
\text { evaluations }\end{array}$ & $\begin{array}{l}\text { Control } \\
\text { Intervention }\end{array}$ & $\begin{array}{l}2.545 \\
3.341\end{array}$ & $\begin{array}{l}1.916 \\
1.746\end{array}$ \\
\hline $\begin{array}{l}\text { Total Critical } \\
\text { Thinking }\end{array}$ & $\begin{array}{l}\text { Control } \\
\text { Intervention }\end{array}$ & $\begin{array}{l}18.12 \\
22.24\end{array}$ & $\begin{array}{l}2.01 \\
2.34\end{array}$ \\
\hline For $\mathrm{p}<.001$ & & & \\
\hline
\end{tabular}

The means of sections listing, solving, defining and comparing of both groups are between 2.3-3.3. These mean scores indicate that students' levels of critical thinking skills were above the average, however, the means of synthesising and evaluating were comparatively higher in the intervention group. When a paired $t$-test was conducted on the data to see whether the teams of students exhibited a higher level of critical thinking between the control and intervention groups. The results reveal that there is a statistically significant difference $(t=3.198 ;$ df $=29 ; p=.003)$ between these two groups. The mean for the intervention group studying critical thinking strategies is 22.24 , revealing a level of critical thinking that is slightly higher than the average, while the mean for the control group is 18.12 , signifying a level of thinking that is slightly below than the intervention group's.

\section{Discussion AND CONCluSions}

Participants in this study showed some improvement in their critical thinking skills through participation in class discussions. Students in the experimental group improved their critical thinking from pretest to posttest. Several factors explain this gain. First, the students in both groups were required to review and analyze case studies related to selfregulation issues many students face. These ill-structured problems were used to motivate the students to complete the task and initiate the analytical cognitive processes. Second, students were specifically instructed in the steps required for effective analyses (i.e., identification of the problem, relevant assumptions, resolutions, etc.) and were required to document the processes by completing an online template of the steps prior to each analysis. Third, students received timely feedback on their analytical reasoning. Students also examined the cases and analytical processes within a class discussion. Fourth, 
students analyzed a total of three cases from pretest to posttest. This would appear to provide adequate practice for the tasks.

The idea that critical thinking must be taught hand in hand with the content is further supported by research on scientific problem solving; that is, when students calculate an answer to a textbook-like problem, rather than design their own experiment. A metaanalysis of the previous experiments investigating methods for teaching scientific problem solving showed that effective approaches were those that focused on building complex, integrated knowledge bases as part of problem solving, for example by including exercises like concept mapping.

This interactive approach to learning asks higher-order questions and requires students to move beyond basic memorization toward a construction of their own understanding. By engaging students in hands-on activities, instructors allow students to become active members in their own education. Students must be allowed to become critical thinkers who ask questions, take risks, and learn through the process. In many cases, when students are encouraged to verbalize their thoughts, those thoughts become more organized. The process of becoming an effective communicator can allow the individual to develop larger vocabulary and gain the abilities to organize thoughts, recognize evidence, and establish the basis for analytical and critical skills (Dance, 2002). To facilitate this interactive process, instructors may need to become better listeners in order to fully understand and respond to student questions and comments (Mazer, Hunt and Kuznekoff, 2007: 90). Teaching students to think critically is high on any teacher's to-do list. Thinking critically should be taught in the context of subject matter. Critical thinking is not just for advanced students. Student experiences offer entrée to complex concepts. To teach critical thinking strategies, make them explicit and practice them.

\section{REFERENCES}

Alfaro LeFevre, R. (1995). Critical Thinking in Nursing: A Practical Approach. W.B.Saunders, Philadelphia.

Allen, M., Berkowitz, S., Hunt, S. and Louden, A. (1999). «A meta-analysis of the impact of forensics and communication education on critical thinking», in Communication Education, 48, 1: 18-30.

Allen, M., Berkowitz, S. and Louden, A. (1995). «A study comparing the impact of communication classes and competitive forensic experience on critical thinking improvement», The Forensic, 81: $1-7$.

Angelo, T. A. (1995). «Classroom assessment for critical thinking», in Teaching of Psychology, 22, 1: $6-7$.

Apps, J.W. (1985). Improving Practice in Continuing Education:Modern Approaches for Understanding the Field and Determining Priorities. San Fransisco: Jossey Bass

Brookfield, S.D. (1987). Developing Critical Thinkers: Challenging Adults to Explore Alternative Ways of Thinking and Acting. San Fransisco: Jossey Bass

Browne, M. N. and Stuart, M. K. (2004). Asking the Right Questions: A Guide to Critical Thinking (7th ed.). Upper Saddle River, NJ: Pearson-Prentice Hall.

Conger M.M. and MezzaI. (1996). «Fostering critical thinking in nursing students in the clinical setting», in Nurse Educator, 21, 3: 11-15. 
Dance, E. X. (2002). «Speech and thought», in Communication Education, 51, 4: 355-359.

Dewey, J. (1938). Experience and Education .New York: Collier Books.

Ennis, R. H. (1989). «Critical thinking and subject specificity: Clarification and needed research», in Educational Researcher, 18, 3, 4-10.

Ennis, R. H. (2003). «Critical thinking assessment», in D. Fasko (ed.), Critical Thinking and Reasoning: Current Research, Theory, and Practice . Cresskill, NJ: Hampton, 293-313.

Facione, P. (1991). Testing college level critical thinking skills. Paper presented at the 11th

Annual Internal Conference on Critical Thinking and Education Reform, Sonoma, California.

Facione, P. A. (1998). Critical thinking: What it is and why it counts. Available from http:// www.calpress.com/pdf_files/what\&why.pdf, accessed 10 May, 2005.

Fink, D. (2003). Creating Significant Learning Experiences,CA: John Wiley and Sons.

Freire, P. (1968). Pedagogy of the Oppressed.New York: The Seabury Press

Gadzella, B. M., Ginther, D. W. and Bryant, G. W. (1997). «Prediction of performance in an academic course by scores on measures of learning style and critical thinking», Psychological Report, 81: 595-602.

Geertz, C. (1973). The Interpretation of Cultures: Selected Essays. New York: Basic Books.

Facione, P.A. (1990). The Delphi Report. Critical Thinking: A Statement of Expert Consensus for Purposes of Educational Assessment and Instruction. Executive summary. Millbrae, California: The California Academic Press.

Ford, J.S. and Profetto McGrath, J. (1994). «A model for critical thinking within the context of curriculum as praxis», in Journal of Nursing Education, 33, 8: 341-344.

Henderson, D.J. (1995). «Consciousness raising in participatory research: method and

methodology for emancipatory nursing inquiry», in Advances in Nursing Science, 17, 3: 58-69.

Holt-Reynolds, D. (2001). «What does the teacher do? Constructivist pedagogies and prospective teacher's beliefs about the role of a teacher», in Teaching and Teacher Education, 16, 1: $1-32$.

Holter, I.M. (1988). «Critical theory: a foundation for the development of nursing theories», in Scholarly Inquiry for Nursing Practice: An International Journal, 2, 3: 223-232.

Hunt, S. K., Novak, D. R., Semlak, J. L. and Meyer, K. R. (2005). «Synthesizing the first 15 years of the Basic Communication Course Annual: «What research tells us about effective pedagogy», in Basic Communication Course Annual, 17, 1-42.

Jacobson, T. E. and Mark, B. L. (2000). «Separating wheat from chaff: Helping first-year students become information savvy» in Journal of General Education, 49, 4: 256-278.

Lehman, D., Lempart, R. E. and Nisbett, R. (1988). «The effects of graduate training on reasoning», in American Psychologist, 43, 6: 431-442.

Lehman, D. and Nisbett, R. (1990). «A longitudinal study of the effects of undergraduate training on reasoning», in Development Psychology, 26, 6: 952-960.

Mazer, J. P., Hunt, S. K. and Kuznekoff, J. H. (2007). "Revýsýng general education: Assessiýng a critical thinking instructional model in the basic communication course», in The Journal Of General Education, 56, 3-4: 174-202

O'Keefe, V. P. (1986). Affecting Critical Thinking through Speech. Annandale, VA: ERIC Clearinghouse on Reading and Communication Skills.

O'Keefe, V. P. (1995). Speaking to Think, Thinking to Speak: The Importance of Talk in the Learning Process. Portsmouth, NH: Boynton/Cook Publishers.

Porter, S. (1994). «New nursing: the road to freedom?», in Journal of Advanced Nursing, 20: 269274. 
Ray, M.A. (1992). «Critical theory as a framework to enhance nursing science», in Nursing Science Quarterly, 5, 98-101.

Sibylle, G. and Boreen, J. (2003). «Teaching Critical Thinking: using experience to promote learning in middle school and college students», in Teachers and Teaching: Theory and Practice, 9, 1: 5-22

Tsui, L. (2000). «Effects of campus culture on students' critical thinking», in Review of Higher Education, 23, 4, 421-441.

Tsui, L. (2001). «Faculty attitudes and the development of students' critical thinking skills», in Journal of General Education, 50, 1: 1-28.

Williams, R. L., Oliver, R., Allin, J. L., Winn, B. and Booher, C. S. (2003). «Psychological critical thinking as a course predictor and outcome variable», Teaching of Psychology, 30, 3: 220 223.

Williams, R. L., Oliver, R. and Stockdale, S. L. (2004). «Psychological versus generic critical thinking as predictors and outcome measures in a large undergraduate human development course», in Journal of General Education, 53, 1: 37-58.

Williams, R. L. and Stockdale, S. L. (2003). «High-performing students with low critical thinking skills», in Journal of General Education, 52, 3: 199-225.

Williams, R. L. and Worth, S. L. (2001). «The relationship of critical thinking to success in college», in Inquiry: Critical Thinking Across the Disciplines, 21, 1, 15-16.

Willingham, D. (2008). «Critical thinking Strategies», in Arts Education Policy Review, 109, 4: 21 29

Wilson, D. G. and Wagner, E. E. (1981). «The Watson-Glaser Critical Thinking Appraisal as a predictor of performance in a critical thinking course», in Educational and Psychological Measurement, 41, 1319-1322. 